
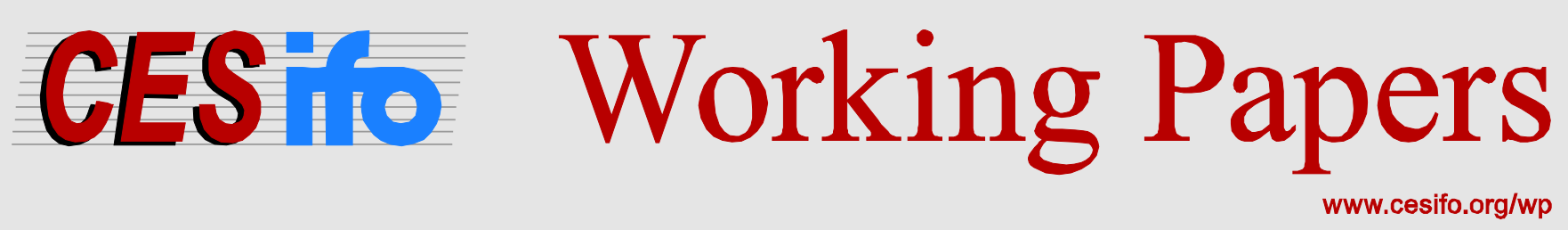

\title{
Quantitative Easing: The Challenge for Households Long-term Savings and Financial Security
}

\author{
Christian Thimann
}

\author{
CESIFO WORKING PAPER NO. 5976 \\ CATEGORY 7: MONETARY POLICY AND INTERNATIONAL FinANCE \\ JUNE 2016
}

An electronic version of the paper may be downloaded

- from the SSRN website: $\quad$ www.SSRN.com

- from the RePEc website: Www.RePEc.org

- from the CESifo website: www.CESifo-group.org/wp 


\title{
Quantitative Easing: The Challenge for Households Long-term Savings and Financial Security
}

\begin{abstract}
The extremely low long-term interest rates in capital markets, to a relevant extent induced by quantitative easing, imply significant challenges for retirement saving and the stability of households' purchasing power over the long-term. The reason is that prices for the two most important long-term savings objectives - housing and healthcare - are rising substantially, while long-term return in safe instruments is virtually zero. Savers face a major dilemma: either they miss long-term savings objectives and see purchasing power decline, or they compromise financial security and invest in highly volatile assets, such as equity, whose return is highly uncertain and potentially negative. This issue is especially relevant in Europe where equity markets are much less developed and where some major European indices are still today trading below the levels reached in the year 2000 .
\end{abstract}

JEL-Codes: E300, E430, E500.

Keywords: quantitative easing, savings, purchasing power.

\author{
Christian Thimann \\ AXA Group \& \\ Paris School of Economics \\ Paris / France \\ christian.thimann@psemail.eu
}

June 2016

This paper was published in French under the title "L'assouplissement quantitatif : un défi pour l'épargne à long terme et la sécurité financière des ménages” in: Revue d'Economie et Financière, no. 121 (2016), p. 213-224. Helpful comments by Mohamed Baccouche and Amelie de Montchalin are gratefully acknowledged. Views expressed are those of the author. 


\section{Introduction}

Quantitative easing (QE) and low short-term interest rates are two distinct forms of central bank action. The latter refers to the rates of interest charged to commercial banks for refinancing operations with the central bank and the conditions in the money market. These standard monetary policy operations are price-driven (the interest rate), bi-directional (the central bank's policy rates can be raised or lowered) and principally involve lending transactions.

By contrast, QE refers to large-scale purchases of mostly government debt securities by the central bank from private investors in the capital market. These operations are quantity-driven (purchase volume), one-directional (buy-side only) and involve ownership transfer of the assets to the central bank. These large debt purchases have direct impacts on capital market functioning and the allocations of private savings and investment portfolios.

Hence, QE is fundamentally different from standard monetary policy operations for three reasons. It intervenes not in the money market but in the long-term capital market. Second, it causes large-scale portfolio shifts, removing safe assets from financial institutions and households. And third, it cannot be quickly reversed - the central bank cannot sell the bonds purchased but has to hold them to maturity, so that the impacts of QE are felt not just over years but over decades.

This short paper draws attention to the implications of QE for households' long-term savings. Specifically, it discusses the implications for the financial security of households, which strongly demand capital guarantees on their long-term savings so as to have financial predictability and be able to plan for retirement income support (especially health services and long-term care) or large asset purchases (typically housing for themselves or their descendants). Such capital guarantees have typically been provided by insurance companies as part of life insurance contracts. The paper also focuses on the price/interest rate gap for specific savings objectives and raises the question of whether a large-scale absorption of savings in housing makes sense from a macroeconomic and household point of view.

The paper makes three points: first, if long-term interest rates are zero, it will be difficult for households to obtain long-term savings guarantees because insurance companies will not be remunerated for the costs and risks it takes to provide such guarantees. This means that households' long-term financial security is compromised.

Second, long-term savers face a catching-up problem, as the savings return are now below the price increase for the two main long-term savings objectives: long-term healthcare and housing. In most relevant markets, the price for long-term healthcare and house purchases rise by 3-6 percent per year, while the long-term savings return in safe assets is now close to zero; this means that savers cannot 'catch up' with rising prices and can thus not secure their longterm savings objectives.

Third, the rising costs of (urban) dwelling implies that a rising part of household income is devoted to expenditure on housing, which means that such savings are not available for more productive use in the economy. 


\section{The nature of quantitative easing}

QE programs are measures with outstandingly long lasting impacts - far beyond the time taken for the usual transmission channel for monetary policy and also far beyond a typical economic cycle. In contrast with interest rate policy, QE programs do not focus on a movement of prices that can be altered at any point in time; rather, they entail portfolio shifts from the private to the public sector that cannot be reversed without risks to financial stability.

Whereas a central bank can reverse its path on monetary policy interest rates without any inertia, it is virtually impossible to sell bonds acquired under QE because this would risk causing financial instability. The 'tapering experience' by the Federal Reserve of summer 2013 shows that even an announcement of a slowdown in purchases, at the time referred to as 'tapering', can have substantial financial stability consequences (Mishra et al., 2014). Moreover, selling large quantities of assets would impose losses on the central bank itself, prices of purchase being artificially inflated by its own action. Even small declines in bond prices would make a central bank with a large QE portfolio technically insolvent if it had to mark its assets to market. ${ }^{1}$

It is also noteworthy that in QE, putting on hold the policy seems difficult and new programs are cascaded onto another even though this was clearly not the intention from the outset. The Federal Reserve started QE1 in December 2008, QE2 in November 2010 and QE3 in September 2012. 'Tapering' was mentioned in summer 2013, started in January 2014 and purchases were stopped only six years after the first launch, in October 2014. At that time, the Federal Reserve had accumulated close to $\$ 4$ trillion of assets of which $\$ 2.5$ trillion of Treasuries, holding as many Treasuries as China and Japan combined (each hold about $\$ 1.2$ trillion; source: US Treasury).

The ECB announced its 'QE1' in January 2015, stating that it would run the program until September 2016; then in December 2015, it announced not only an extension of the horizon until at least Q1-2017 but also of the scope of assets to include local and regional debt so that one can speak of 'QE2'. And only three months later, in March 2016, it announced an increase in the monthly purchase volume from EUR 60 billion to EUR 80 billion and further extended the perimeter to include also corporate debt - so that one can speak of ' $Q E 3$ '. The immediate market impact was not always as desired (Table 1).

\footnotetext{
${ }^{1}$ It should be noted that a central bank can continue to operate even though it is undercapitalised or technically insolvent; there have been a few such cases in recent history, with the case of the central bank of Chile being one of the more prominent ones; see Stella and Lonnenberg (2008).
} 
Table 1. Overview of ECB quantitative easing (QE) programs

\begin{tabular}{|l|l|l|l|l|l|}
\hline \multirow{2}{*}{ Program } & \multicolumn{2}{c}{ Date } & \multicolumn{2}{c}{ Scope } & \multicolumn{2}{l|}{ Volume } & Duration & \multicolumn{1}{l|}{$\begin{array}{l}\text { Immediate market } \\
\text { impact }\end{array}$} \\
\hline QE1 & $\begin{array}{l}\text { January } \\
2015\end{array}$ & $\begin{array}{l}\text { Central } \\
\text { government } \\
\text { debt }\end{array}$ & $\begin{array}{l}€ 60 \text { billion } \\
\text { per month }\end{array}$ & $\begin{array}{l}\text { Until Sept } \\
2016\end{array}$ & Intended direction \\
\hline QE 2 & $\begin{array}{l}\text { December } \\
\text { + regional } \\
\text { and local } \\
\text { government } \\
\text { debt }\end{array}$ & $\begin{array}{l}€ 60 \text { billion } \\
\text { per month }\end{array}$ & $\begin{array}{l}\text { Until } \\
\text { March }\end{array}$ & Unintended direction \\
\hline QE3 & $\begin{array}{l}\text { March } \\
\text { + corporate } \\
\text { debt }\end{array}$ & $\begin{array}{l}€ 80 \text { billion } \\
\text { per month }\end{array}$ & $\begin{array}{l}\text { Until } \\
\text { March } \\
2016\end{array}$ & $\begin{array}{l}\text { Unprecedented } \\
\text { volatility }\end{array}$ \\
\hline
\end{tabular}

There are three channels through which QE is supposed to affect the real economy (Bean et al., 2015, p. 67ff): the bank liquidity channel, the policy-signaling channel and the portfolio effect channel.

Of these three channels, the last one is the most important at stake since the ECB QE launch. This is easily seen, as the ECB had already been in full liquidity allotment mode for many years and had given all assurance to the banking system that it would fulfil liquidity needs in a virtually unrestricted manner; moreover, the ECB had also already implemented 'forward guidance' in order to signal its policy intentions (ECB decision 4 July 2013). What QE therefore added in qualitative terms was an immense shift of safe assets from the private sector to the central bank's balance sheet of what from today's perspective is expected to be about EUR 1.5-2.0 trillion of assets, an amount close to the GDP of France and more than the half of Germany.

Even if purchases were to be stopped in 2017 as announced, the portfolio channel would be operating in principle until 2047 to the extent that 30-years bonds have been purchased. And its effect will be still half its peak effect in 2025 for the euro area as a whole (Figure 1), as the average maturity of the bond portfolio is about eight years (source: ECB). This highlights the need to think the potential consequences of $\mathrm{QE}$ as being long-term ones, a scenario of a quick 'normalization' not being plausible. 


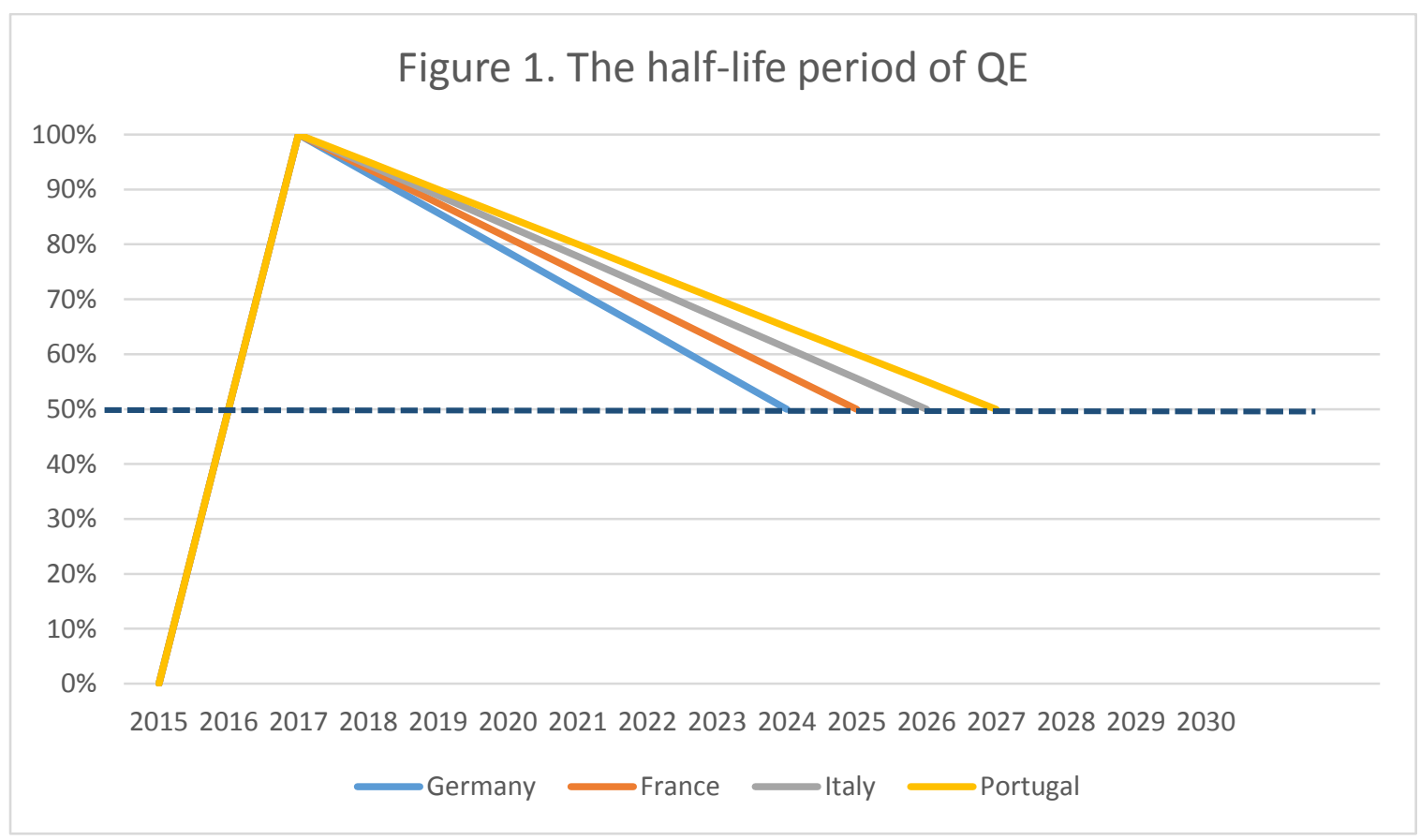

Note: This figure illustrates the long-term dimension of quantitative easing, arising from the long maturities of the debt purchased and the effect that the central bank as to hold them to maturity. Overall, the remaining maturity of bonds purchased ranges from about seven years for Germany to above ten years for Portugal, so that $50 \%$ of the portfolio effect will be felt still in 2024-2027 in these countries, even if purchases are stopped in 2017.

\section{The social stability challenge arising from $Q E$}

\section{a. What if guarantees are compromised?}

Security is a basic human need. In the Maslow's famous pyramid of needs, it is the most fundamental need after purely physiological needs. There is no doubt at the individual level that financial security is part of overall security and mental well-being, and that by inversion, financial insecurity is a source of stress (Rohde, Ki Tang, Osberg and Rao 2014).

This explains why guarantees are an essential component of long-term savings. Such security is particularly important when it requires the accumulation of large-scale funds, such as for house purchases or health expenditures that are a very important stream of income during retirement.

One might conjecture that the situation of zero interest rates is not incompatible with these needs because guarantees might still be offered even if the returns might be nil. But this is a fallacy because there are costs for the insurance company of providing guarantees and the interest rate no longer covers such costs. Moreover, the costs of the provision of a guarantee are actually higher when rates are zero than when rates are positive because the probability to be in negative territory is greater. 
Guarantees are usually provided in all standard life and savings insurance contracts throughout Europe. Such guarantees are in most cases the guarantee of the principal invested, sometimes they also include the guarantees of the past returns accumulated or a fraction thereof and in other cases a certain positive return is guaranteed. What is more, such contracts are usually endowed with protection benefit for family members in case of the death of the policyholder. It is this whole set of arrangements that provide peace of mind.

The administration of these contracts and the provision of the financial guarantee is costly, as the provider has to cover the risk of death of the policyholder (mortality risk) and the market risk in case the policyholder cashes in his or her contract before the planned date (lapse risk) or at a moment when the market conditions are deteriorated and the principal invested under risk (market risk). So far, the positive return of government bond markets has allowed covering for these risks and the administrative costs, while representing an overall safe return. If the return on safe assets is near zero, the provision of such guarantees is compromised.

Figure 2. The 'triangle of desires' in long-term saving/investment Guarantees/security

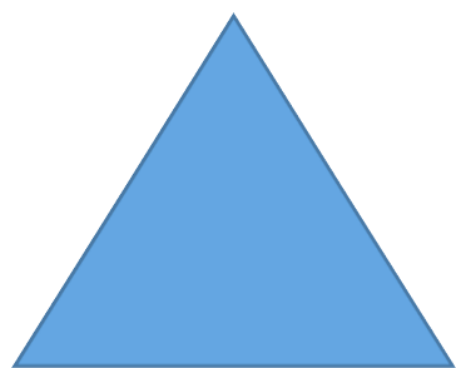

Return

Liquidity

Note: For explanations see text.

Long-term savers desire three features for their investment (Figure 2): a guarantee of paid-in capital to provide financial security; a financial return to maintain living standards in old age; and liquidity to access the funds if unforeseen circumstances arise.

Before QE, savers could fulfil these desires through life insurance contracts funded through an investment mix based on government bonds, investment-grade corporate bonds and a limited investment in equities. These contracts represent the backbone of household savings: in France, EUR 1,500 billion euro are invested in life insurance products (of which EUR 1,300 billion are invested in the guaranteed form of it). In Germany more than 90 million such insurance contracts exist, $50 \%$ more than the adult population.

In the new environment, which combines low to absent returns on safe assets and substantial financial market volatility, it is even challenging to provide two of the three features. 
What are possible ways to deal with this issue? One option sometimes proposed by regulators is to stop providing such long-term guarantees to offer a mix of return and liquidity. This is hypothetically possible for the insurance companies but would leave the demand for guarantees unaddressed. Hence, this recommendation is to the detriment of households' financial security.

Another option would be for insurance companies to invest more in higher-yielding assets such as equity markets that have been boosted by QE, albeit in a context of heightened financial market volatility. However, insurance companies are not free to choose their investment pattern, which is highly regulated, in particular by capital charges. For any investment in government bonds in the standard model, the capital charge is zero; for investment in equities, it is $39 \%$ (Solvency II capital charges in the standard model).

The only way out that would make it possible still to provide guarantees and some returns would be to lower the degree of liquidity and raise the share of non-sovereign investment. But this would only be feasible if regulation provided for this possibility and if the capital charge framework was adjusted for such products. Why a positive return is so important for longterm savers - and potentially more than access to liquidity - will be discussed in the next section.

\section{b. What if the returns on savings are lower than the price increases of the products for which people save?}

Low interest rates are often equated with low inflation. It is said that QE is aiming at avoiding deflation and at raising inflation rates, which are currently very low. But this broad-brush assessment passes over a crucial problem and misses the point as far as long-term savings are concerned.

There are two main motives why people put funds aside and save for the long term: to provide income for retirement, supplementing public or corporate pensions that are generally seen as insufficient, particularly in view of the demographic challenges and the unsustainability of some of Europe's pension systems; and to buy a home, either for themselves or to help their children to do so.

Looking more closely at the motives to provide for supplementary income in retirement reveals that it is not daily expenses that are critical but the concern to provide a cushion for healthcare expenditures, which are essentially concentrated in the older age. Specifically, many people wish to be able to afford healthcare at home so as to stay at home even if their health situation deteriorates, to care for their partner or their elderly dependents.

This means that two sets of prices are most relevant for long-term savings: healthcare and housing.

The striking fact is that both of these expenditure goals - health and housing - have price dynamics that are totally different from the ones in the general consumer price basket used as a reference to assess inflation by policy makers. 


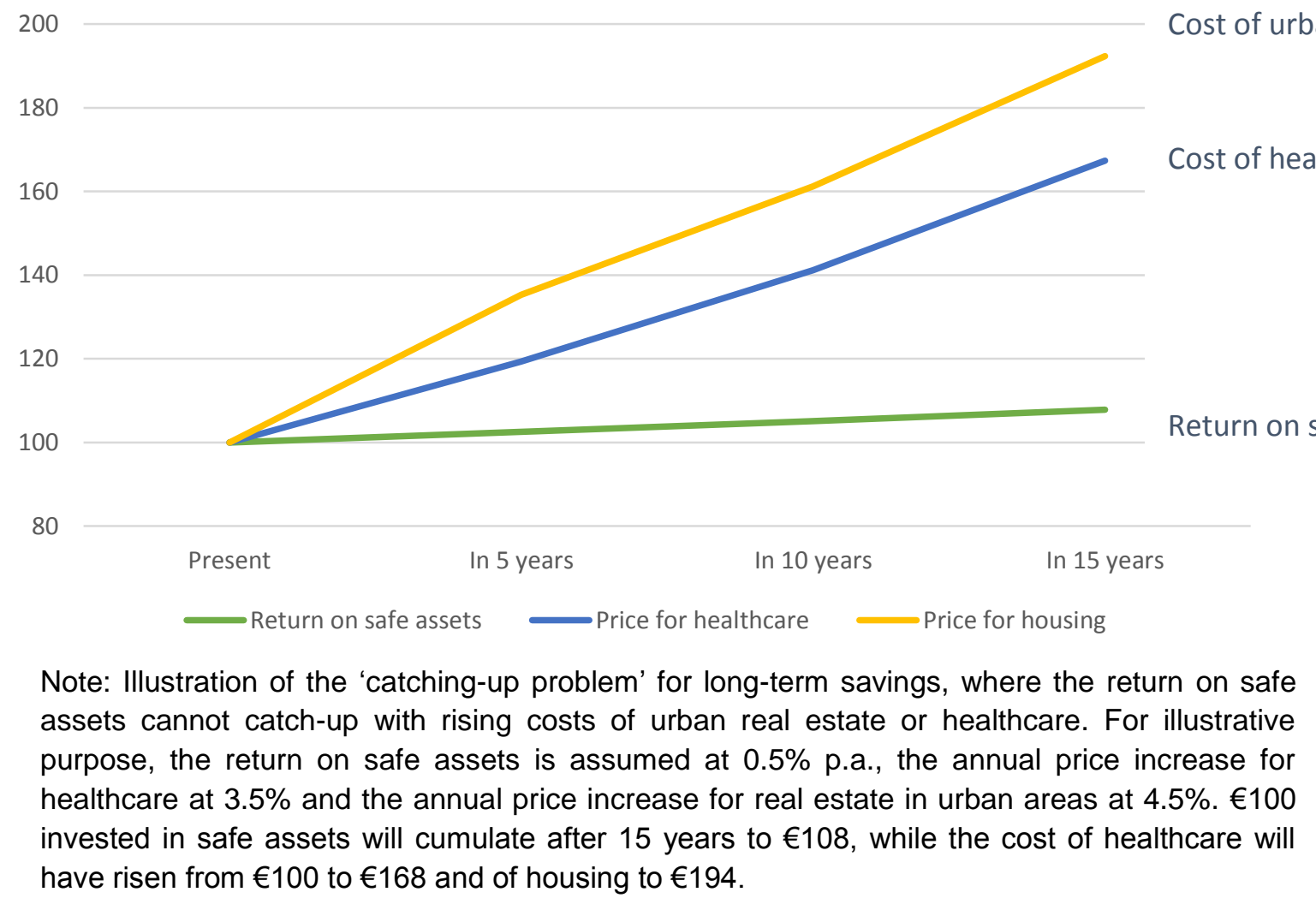

Healthcare, pharmaceutical products and long-term care are all offered to date in a context of low competition and high concentration that entails low pressure on price while covering essential needs. Healthcare prices including medication, equipment and treatment, as well as nursing and retirement homes prices, are among the fastest rising price components in the CPI basket rising about $5 \%$ per year or more. ${ }^{2}$

The current demographic trends with rising shares of the elderly and fewer young people including fewer healthcare personnel - will drive up health prices even further. As a reference, public old-age retirement homes net costs reached in 2015 on average $€ 2,000 /$ month per person in France - while median income of retirees only reaches $€ 1,500 /$ month and direct public pension income $€ 1,250 /$ month for men and $€ 900 /$ month for women.

House prices have also been rising significantly, and ironically this has been partly driven by QE, as lower interest rates and easier credit conditions increased demand for housing ownership, by increasing the relative capacity for households to borrow and buy a home rather than renting one. The euro area average price is not relevant here, but house price

\footnotetext{
${ }^{2}$ Health prices are considered net of administrative reimbursements in the HICP, whereas the CPI uses the 'gross' prices, which are representative of the purchase price of the products consumed. With the expected trend decline in the share of administrative reimbursements, the weight of health prices in the HICP can be expected to increase.
} 
developments in cities and broader urban areas because this is where the jobs are. Such house prices have been rising by $4 \%$ or more in recent periods, and the trend is continuing unabated.

All this is to argue that in order to determine the target return of long-term savings, it is not the average inflation rate that is relevant but the price dynamics of the specific expenditure behind the objectives of long-term savings. And for those components, safe assets, and sovereign bonds in particular, do not provide sufficient return. This is the catching-up problem: savers cannot catch up with rising prices for key long-term savings objectives, even if they start saving very early and steadily (Figure 3).

In other words, people have been moved from a world in which they could cover long-term saving needs with safe financial instruments to a world in which this is no longer possible - or only possible individually at a high risk by investing in volatile assets with higher potential returns but the risk of losing on the investment.

It is sometimes argued that households should get used to invest more in equities, but equity markets in Europe are smaller than in the US, there is no tradition of equity investment and losses are frequent: in early 2000, the CAC40 index stood at above 6,000 points; 16 years later, it stands at 4,400 points.

Therefore, people are forced to choose between two forms of insecurity: insecurity on asset returns; or insecurity on outcomes through a relative impoverishment because they will not accumulate sufficient funds to cover for their own and family's needs. The first strategy consists of maximizing the potential return and can be chosen by the wealthier, less riskaverse part of the population; the second strategy consists of minimizing the losses and is vital for the largest share of the population.

\section{c. What if low interest rates create further incentives for people to invest in real estate?}

Stating that rising house prices make people wealthier and better off turns out to be a fallacy at closer inspection. It would be true if one considered the household as an economic agent with a balance sheet, the value of home ownership is rising on the asset side. But there is little benefit the household can draw from higher house prices, while there are substantial social costs.

In the United States, higher house prices allowed people to take mortgages on the house to finance current expenditures, but there is a very different bankruptcy system in the United States and the situation has also led many households into distress due to overborrowing and overspending. In Europe this is generally not possible. Therefore the only way to realise the wealth increase would be to sell the house, but one would then need to buy another house whose higher price will wipe out any gain, or live in a smaller house, or further from the cities to take advantage of the now liquid "realized gain".

While there may be benefits of higher house prices, for example by attracting more investment and higher wealth for households that can sell a house without having to buy another one to live in, there are also a number of costs and risks related to higher house prices. 


\section{Conclusion}

Whatever the monetary policy validity of large-scale purchases of debt securities by the central bank, such quantitative easing operations have far-reaching long-term implications through the portfolio shift they entail. They deprive banks, other institutional investors and households of savings instruments that were the 'bread and butter' of long-term investment and savings.

It seems likely that up to $€ 2$ trillion of plain-vanilla debt instruments - central government bonds, regional government bonds and bonds issued by large corporates - will be removed from private portfolios and placed with the central bank; they will no longer be available as the backbone of long-term private stable financial plans. These securities combined the unique features of safety and reasonable returns that allowed individuals and families to augment prospective retirement income, complementing public pension schemes that are growingly insufficient in most European countries to maintain living standards in retirement.

By removing or massively reducing the available stock of safe assets, financial market functioning will also be deeply affected. One can think of financial markets and the pricing of assets in form of concentric circles, with government bonds at the centre; in the first circle, corporate bonds, which are generally priced at a mark-up on government bonds; in the second circle, equities, which are generally priced at a mark-up on corporate bonds; and in the following circles, structured finance, alternative investments, private equity and finally infrastructure. Fuelling expectations of higher government bond prices will actually move more demand to the center.

As far as the banking system is concerned, removing government bonds from banks' balance sheets cannot entail a straightforward portfolio reallocation to private sector lending. First, lending requires the use of capital, which is not necessary to hold government bonds; and second, banks do not lend because they have cash available but because they see favourable risk-return profiles in lending opportunities. The effect of $\mathrm{QE}$ on the latter has not yet materialized - otherwise, there would not have been a perceived need to add a second and a third version of the programme in little more than twelve months.

QE functions fundamentally differently in a bank-based system than in a market-based system where investors operate in much less regulated environment and where the available stock of all kinds of debt securities is much larger and the investment options therefore much more numerous to preserve stable, long-term and liquid saving tools.

This paper does not call into question the monetary policy validity of QE, its monetary dimension, price impact or exchange rate effect. It does, however, highlight the social stability implications for the long haul, which one can already see will be very significant. 


\section{References}

Bean, C., C. Broda, T. Ito and R. Kroszner (2015): Low for Long. Causes and Consequences of Persistently Low Interest Rates. Geneva Reports on the World Economy no. 17 and CEPR book, Geneva and London.

Mishra, P., K. Moriyama, P. N'Diaye and L. Nguyen (2014): 'Impact of Fed Tapering Announcements on Emerging Markets', IMF Working Paper WP/14/109, International Monetary Fund, Washington D.C.

Rohde, N., K. Tang, L. Osberg and D. Rao (2014): 'The Effect of Economic Insecurity on Mental Health: Recent Evidence from Australian Panel Data'

Stella, P. and A. Lonnenberg (2008): 'Issues in Central Bank Finance and Independence', IMF Working Paper WP/08/37, International Monetary Fund, Washington D.C. 